UDC 349.6.001

DOI https://doi.org/10.37687/2413-7189.2019.4.6

\author{
Sydor V.D., \\ $\mathrm{PhD}, \mathrm{DSc}$, \\ Professor at the Constitutional, Administrative and International Law Department \\ of the Kyiv Institute of Intellectual Property and Law \\ of the National University "Odesa Law Academy" \\ ORCID: 0000-0002-1794-2577
}

\title{
PROSPECTS OF CODIFICATION OF ENVIRONMENTAL LEGISLATION OF UKRAINE
}

\section{ПЕРСПЕКТИВИ КОДИФІКАЦІЇ ЕКОЛОГІЧНОГО ЗАКОНОДАВСТВА УКРАЇНИ}

The article is devoted to the analysis and generalization of theoretical and normative approaches to the codification of environmental legislation, the identification of the main tendencies and forms of codification of environmental legislation and peculiarities of their application in Ukraine. It is established that the systematization of environmental legislation is carried out using the classical technical and legal arsenal of methods, means and forms. The main forms of systematization of legislative acts are as follows: accounting; incorporation; consolidation; codification. The author argues that an important area of improvement of environmental legislation is the systematization of its concepts and terms. The idea in the doctrine of environmental law is that the Ecological Code is the optimal form of systematization. The preparatory work to be carried out before the start of codification is characterized: determination of the number and volume of normative legal acts to be processed; collection of regulatory material and their analysis in order to eliminate contradictions and duplications. The basic legal prerequisites for codification of environmental legislation are identified: the stability of environmental legislation; internal unity of environmental legislation; maximum compliance of the environmental law system and the environmental legislation system; availability of law enforcement practices; scientific substantiation of codification; systematic approach to environmental legislation. The idea that the codification of environmental legislation will ensure the coherence of norms and legal institutions and clear out of outdated and ineffective norms is substantiated.

Key words: environmental relations, environmental legislation, environmental law, systematization, codification, Environmental Code.

Стаття присвячена аналізу та узагальненню теоретичних та нормативних підходів до кодифікації екологічного законодавства, виявленню основних тендениій та форм проведення кодифікаиії екологічного законодавства та особливостей їх застосування в Украӥні. Встановлено, щчо систематизація екологічного законодавства проводиться за допомогою класичного техніко-правового арсеналу методів, засобів та форм. Основними формами систематизаиії нормативних законодавчих актів є такі як: бухгалтерський облік; інкорпорація; консолідація; кодифікація. Автор доводить, щз важливим напрямом удосконалення екологічного законодавства є систематизаиія його понять та термінів. Підтримано наявну в доктрині екологічного права ідею про те, щчо оптимальною формою систематизачії є Екологічний кодекс. Охарактеризовано підготовчі роботи, щзо мають бути проведені перед початком кодифікації: визначення кількості та обсягу нормативно-правових актів, щзо підлягають обробиі; збір нормативного матеріалу та їх аналіз з метою усунення протиріч та дублювань. Визначено основні правові передумови кодифікаиії екологічного законодавства, такі як: стабільність екологічного законодавства; внутрішня єдність екологічного законодавства; максимальна відповідність системи екологічного права та системи екологічного законодавства; наявність правозастосовчої практики; наукове обтрунтування кодифікаиї; системний підхід до екологічного законодавства. Обгрунтовано ідею, щзо кодифікація екологічного законодавства дасть змогу забезпечити узгодженість норм та правових інститутів та очистити від застарілих та неефективних норм.

Ключові слова: екологічні відносини, екологічне законодавство, екологічне право, систематизачія, кодифікація, Екологічний кодекс.

Introduction. In the modern environmental law one can often find conflicting legal acts or amendments caused by political and economic interests of different political forces. Well-conducted systematization will ensure the stability of the environmental legislation, and it will strengthen legitimacy of its relations. Organization of the legal normative materials can play a mobilizing role in the law-making process, and the effective usage of the methods of the organization will help to identify and promptly close the gaps in the existing environmental legislation of Ukraine.

One of the main disadvantages of the current environmental laws is their inner contradictions, the existence of the large number of gaps, excessive variety of the normative legislative regulations, etc. To address the existing shortcomings of the modern environmental law its systematization is absolutely necessary, which is the activity directed to streamline the broad array of legal normative acts, combining them into a unified and coherent system. Modern systematization of the environmental legislation is a complex process of the understanding of the social practices of the environmental relations regulations, demands that have been imposed by them, and normative incorporation of these requirements into the legislative and regulatory acts. 
Scientific study of the problem. The issues of the expediency of environmental legislation codification have been already studied in the papers of V.I. Andreytsev [1], G.V. Avisimova [2], P.O. Gvozdik [3], A.P. Hetman [4], I.I. Karakash [5], V.V. Kostytsky [6], N.R. Malysheva [7], Yu.S. Shemshuchenko [8], M.V. Shulga [2], A.K. Sokolova [9] and other scientists.

The aim of the publication is generalization of theoretical and normative approaches to the codification of environmental legislation, identification of the main tendencies and forms of environmental codification and features of their application in Ukraine.

Content. Judicial norms governing environmental relations should be aligned with the new level of the economic development. As a unique mechanism of achieving social cooperation, which is based on the superiority of the Constitution of Ukraine, the judicial branch imposes a rather complicated task of the aligning of the legislative norms governing the environmental relationships. Because of this, the problem of ensuring consistency of existing normative legislative acts is of a particular relevance.

A significant change in the environmental laws and relations demands a fundamental alteration of the environmental legislative system. It is possible to identify two stages of this process:

1) the first one is the development of the necessary environmental legislative norms and the legislative base governing the environmental relationships. The quantity of the norms is of the great importance during this stage;

2 ) the second stage involves the systematization of the normative materials, and the quality plays a significant role here. We believe that Ukraine has already passed the first stage and is gradually moving towards the second one. The necessity of such transition is confirmed by the existing deficiencies of the environmental law system and the environmental regulations of the current stage.

Without systematization of the normative legislative acts it will be impossible to improve the legislation, to organize it in the specific system, and an inadequacy or a lack of the systematization of the normative materials will cause problems in the process of the lawmaking. The theory of the systematization depends on the understanding of the government and law structures and receives the necessary information from the streamlining and improving of the legislation. During the process of the current systematization of the legislation, one should take into account the structural formations of the legislation, which are the areas of the legislative regulations.

Spontaneity of the environmental legislation development is largely caused by the absence of the adequate necessary foundational plans for this activity. It is considered purposeful to conduct this activity considering a state program of the legislation. The determining factor, which affects the quality and content of the legislation is providing the scientific foundation for the legislation, the organization of drafting and coordinating efforts of all branches of the government at all stages of the legislative process. The success of the process depends on the appropriate incorporation of scientifically and practically determined methods of the environmental law research and their practical applications, which are mostly the methodology of studying and evaluating of the current environmental legislation, predicting its development in regard of the social necessity, clarification and justification of its appropriate changes and additions.

In order to form a quality new system of environmental laws, identification of the dynamics and priorities in the field of the environmental legislation, the advancement the level of effectiveness of the law regulations of the environmental relationships, it is necessary to develop and adapt the Concept of the development of the environmental legislation of Ukraine. It should also be important to forecast the most important actions taken to update the individual institutions of the environmental legislation and start a largescale process of the systematization of the legislation.

Because of the unsystematic norm development of the modern environmental legislation and regulations, the following negative traits are present: an unnecessary variety of the legal acts, particularly the Cabinet of Ministers of Ukraine and some ministries and departments' ones, which affect the process of the law-making negatively, inadequate level of the normative regulation in some important areas of the public relations, the predominance of normative acts of institutional character, narrowing the circle of the social relationships that are the subject of the legal regulations, a significant number of gaps, inconsistencies and contradictions.

In modern circumstances the systematization of the legislation is done with the help of the classic technolegal arsenal of methods (ways, techniques), means and forms. The main forms of the systematization of the normative legislative acts are the following:

(a) the collection of the current normative legislative acts by government agencies, enterprises, institutions and other organizations, their handling and classification according to a defined system, storage and delivery of the information to the interested parties at their request (Accounting);

(b) preparation and publication of various publications (Incorporation);

(c) preparation and adoption of more complicated acts based on the consolidation of the different normative acts (Consolidation);

(d) preparation and adaption of the new acts, which incorporate the norms of the previous acts as well as new normative regulations (Codification).

A unique and indispensable preparatory stage of the systematic legal cycle is its inventory, which incorporates the identification in the official manner of the acts that have lost their power or have been altered by the new legislation. The simplest form of the systematization of the legislation is the registration, which can be obtained by categorizing the normative legislative acts in the specific subjects blocks or units. The organization of the registration should be based on the following principles: 
- completeness of the informational mess, which guarantees the correction and granting of total supplemental information;

- the lack of gaps and omissions in it;

- accuracy of information, based on the use of the official sources - published regulations, as well as timely made changes in the acts included in the Information Fund;

- easy usage required for operational and qualitative data search.

The main results of the inventory and accounting are:

- regulation of a wide range of acts, taking into account their specific features and ordering;

- exclusion or at least limitation of the duplication of rules in different branches of the law;

- elimination of gaps to overcome conflicts in the legislation, creation of the conditions relevant legal qualifications.

For the purpose of greater accessibility and proper implementation of the norm-legislative acts current environmental legislation status of Ukraine should be viewed through the prism of its consistency. Today one should actively carry out technical processing of the environmental legislation, eliminate existing contradictions and duplication in order to ensure its stability and effective implementation of the regulatory requirements.

The objective conditions for the active usage of this form of organization have been formed, as incorporation, which does not make changes in the content of the normlegislative acts, and limits to the exterior development of the required material. Incorporation aimed at streamlining norm-legislative acts by their external processing and systematic (in chronological, subject, or other order) associations in a single collection.

At the stage of chronological and systematic incorporation the complete system of the norm-legislative acts is identified. Incorporation of the legislation provides convenience to use norm-legislative acts, helps eliminate gaps and contradictions, gives the possibility of the elimination of the unsubstantiated reference to the presence or absence of the certain legal requirements. Quality incorporation could be the basis for deciding whether to usage is appropriate at a later stage of the systematization of other forms of the systematization of the environmental law. Incorporation promotes the most efficient usage of methods and techniques of legislative technology in the preparation of the text of the Code; gives the possibility to avoid appearing in the text of the temporary regulations, operational nature, promotes consideration of all blank rules.

One of the promising areas of improvement of the environmental legislation can be considered the systematization of its conceptual material. This area is very important due to the introduction of many new concepts and their definitions in the environmental legislation.

We believe that the existing tradition of including new specialized articles in laws that contain explanations of concepts (terms) used in this particular act is very effective. The formation of the system of terms and concepts set forth in the environmental legislation is extremely important, as there are frequent instances of different formulations of the same terms in different legislative acts, in addition, a concept used in the laws are not always properly detailed in subordinate normlegislative acts.

Incorporation of the definitions will be able to reveal contradictory and ambiguous interpretation of the assigned concepts, identify the most correct terms, facilitate their adjustment during the legislative activity, eliminate duplicating definitions.

Since 1990 the official incorporation of the legislative acts in the environmental legislation hasn't been made in Ukraine despite their large number. Incorporation of the environmental law, which was conducted by law scientists does not cover the entire array of the legislative acts, that are partial, and regulations are based largely on the chronological approach to incorporation.

Conducting general incorporation of the environmental legislation in electronic form is followed by the maintaining it up to date for the further codification of the environmental law, so that you can detect collisions and gaps in the normlegislative regulation, cases of the duplication of legal regulations and outdated regulations, assess the effectiveness of the individual institutions of the environmental law.

After implementation of the incorporation it is necessary to implement a systematic grouping of the legislative texts of the acts and their analysis. Consolidation as a mean of the improving of the normative base can be effectively used here. Consolidation of the environmental law is a form the systematization of the legislation, which is to eliminate multiplicity and inconsistency of similar in content legislative acts by merging them without major changes in their content.

The goal of consolidation is to eliminate multiplicity of the legislative acts, creating the structure blocks of normative material as a starting base for the codification work. Consolidation is a specific kind of systematization of the legislation, which ultimate objective is to eliminate the multiplicity of regulations, their unification and the formation of the structure of the law of large homogeneous blocks as a very important intermediate link between the processes of the law-making and codification.

Further development of the environmental legislation is focused on the institutional direction, which should take into account the dynamics of the legislative process. The institutional principle of the environmental law comes to the front, and yet will stay mostly in the legislative process. The systematization of the legislation also requires the institutionalization that is such consolidation of the legislative material aimed at the formation of the separate legal institutions or their arrangement without the adaptation of the relevant code.

Dynamic development of the environmental legislation of Ukraine actualizes its problems of consolidation and institutionalization. Work on the consolidation and institutionalization should 
be based on the provisions of the Constitution of Ukraine. However, the effective consolidation and institutionalization of the environmental law is impossible without serious scientific support of this work. Consolidation and institutionalization of the environmental laws should be considered as part of work to streamline the entire legal system, that is, as an element of a sound and consistent legal policy concept that defines the direction and form of the improvement and development of the modern Ukrainian state and national legal system. With the consolidation and institutionalization most cases of excessive detailing of the subject of regulation can be eliminated, consequently, a reduced number of existing normlegislative acts of the environmental legislation.

Codification of the environmental law is a form of the radical changes of the existing normative acts, the method of qualitative improvement of the legislation, ensuring its consistency and compactness as well as clearing regulatory array exemption from outdated norms that do not justify themselves. Codification creates activities aimed to recycle legislation through the preparation and adoption of the new synthesis, legally coherent and internally consistent codified act. Codification involves streamlining of the legislative materials by eliminating repetitions, contradictions, closing gaps, changing the nature and direction of the material. The result of this activity is the creation of a new norm-legislative act that is carried out by a profound and comprehensive changes of the legislation and changing it significantly.

Codification contributes to the stability of the law. Codification combines the features of law-making (result of codification creates a new legal act) and systematic (in the process of codification collisions, repetitions, contradictions, lack of unity and consistency of the laws are overcome). Codification is a way of improving of the environmental legislation aimed to develope the most adequate objective grounds of regulatory requirements, and the selection of legal material at the same time.

Principles of the environmental law codification can be divided into general and special. General principles are: supremacy of the law, justice, lawfulness, democracy, transparency, humanism, scholarship, professionalism, efficiency of the codification, harmonization of national legislation with the EU legislation. Special principles are: technical and legal perfection of the codification acts, completeness, striving to resolve the complex relationships that combined the sole object, system consistency of the content of the normative act.

The main features of codification acts are the legal integrity and high internal consistency, stability, regulation of a wide range of relationships and complex structure.

The stages of codification work are:

- determining the amount of material to be processed (at this stage to clarify exactly which laws codify or relate to this process regulations that specify the provisions of the law, or subject to codification acts containing technical, economic, technological and other special rules);
- collecting material and its analysis (provides relief from acts that were officially abolished, determine the possibility of the usage of certain legal provisions of the acts that actually don't operate, but not abolished, excluding the introductory parts of the law articles that are not normative, distribution of the legislative material to the relevant departments, elimination of contradictions between the norms that regulate such social relations, identify gaps and close them).

A codification of the environmental legislation today does not correspond to trends in the regulation of the environmental relations. In modern conditions the codification of the environmental law should be made not on the principle "from the concept - to the structure, from the structure - to the text". Regulatory material must be contained in a single document - the Code containing reasonable changes to existing regulations aimed to eliminate problems encountered in the application of the existing legislation.

Not necessarily all the rules insured in law level acts deserve the inclusion in the codified act, while some of the provisions contained in a subordinate regulations may be worthy of inclusion in the Code. In preparing the text of amendments to the legislation acts ideology changes should not be a mechanical reproduction of the Code in other acts, and the maximum reduction of the number of these acts, saving the effect only those acts that can not be for various reasons "absorbed" by the Code. However, even in such acts the provisions of the Code should not be reproduced.

The maximum that can be assumed - is placing blank warrant that indicate regulation of the relations by the Code. Preservation of the environmental norms in the legislation outside the Code is allowed only in exceptional cases where the act is so narrow in scope that the inclusion of the environmental law norms from it to the Code is impractical.

Conclusions. The main legal criteria under which the codification of environmental legislation is possible are: the stability of the environmental legislation; internal unity of the environmental legislation; the maximum match of the environmental law system and the environmental legislation system; the existence of the practical application of the environmental law and its generalization; systematization of the scientific validity (the existence of the concept of the environmental law); the systematic approach to the environmental legislation.

Sequence of the codification works should include: inventory of the existing environmental laws; identification of the conflicts and gaps, repetitions and their elimination; changes of the normative material in accordance with the conceptual framework of the codification; development of the text of the regulation; preparing text of changes to the regulations applicable law, the development of a list of acts that are subject to cancellation.

The Code should have the organizational value because, as a codified act, it should create the foundation of the development of the national environmental legislation. The Code should play an integrating role in the environmental law. It formulates the main 
environmental and legal concepts, establishes principles of legal regulation of the environmental relations, is determined by the legal regime of the various categories and the legal status of the subjects of the environmental relations, establishes guarantees of their rights and more. The Code as a result of the process of organizing of the environmental laws should be stable, which promotes sustainable practices regulating the environmental relations, improves the security of the environmental rights of different subjects, ensure the effectiveness of the environmental regulation.

Legal value of the Code as an external expression of the existence of the special rules and legal environmental rights lies in its ability to use legal mechanisms to ensure the acquisition and sale of the environmental rights among different stakeholders of the environmental relationships to meet their needs and interests. Systematization is an important tool to determine the proper content of the environmental law and their appropriate application in practice is an effective way of providing a wide range of subjects of the environmental relations necessary legal information.

Systematic allocation of the environmental regulations enables law-making bodies to identify existing gaps in the environmental law and conflict and take measures to eliminate them. One of the promising directions of the improvement of the environmental legislation can be seen ordering his conceptual material in the introduction to the environmental law of large number of new concepts and their definitions. Systematization of the environmental legislation should be based on a single scientific concept, which main provisions is to define goals and objectives of the systematic environmental laws, forms its systematization in a particular stage of the development, selection criteria regulations that are systematized.

\section{References:}

1. Андрейцев B.I. Об’єктивні чинники кодифікації законодавства суверенної України: перспективи реалізації конституційних еколого-правових імперативів. Університетські наукові записки. 2012. № 1. С. $25-39$.

2. Анісімова Г.В., Шульга М.В. Теоретичні засади систематизації екологічного законодавства України. Вісник Академії правових наук України. 2009. Вип. 3(54). С. 191-205.

3. Гвоздик П.О. Концептуальні підходи щодо підготовки Екологічного кодексу України. Актуальні проблеми вдосконалення чинного законодавства України. 2012. Вип. 28. С. 223-229.

4. Гетьман А.П. Кодифікація екологічного законодавства в контексті конституційної реформи. Екологічне право Украӥни. 2016. № 1-2. С. 3-5.

5. Каракаш I.I. Актуальні проблеми систематизації сучасного екологічного законодавства України. Актуальні проблеми держави і права. 2018. С. 63-71.

6. Костицький В.В. Методологічні проблеми кодифікації екологічного законодавства. Філософські, методологічні та психологічні проблеми права : матеріали II Всеукраїнської науково-практичної конференції (31 січня 2009 р., м. Київ). Київ : Київський національний університет внутрішніх справ. С. 78-81.

7. Малишева Н.Р., Олещенко В.І. Наукові засади систематизації екологічного законодавства України. Правова держава. 2015. Вип. 26. С. 307-318.

8. Шемшученко Ю.С. Питання кодифікації українського екологічного законодавства. Украӥнське право. 1994. № 1. С. 33-38.

9. Соколова А.К. Правові проблеми систематизації екологічного законодавства України. Проблеми законності. 2012. Вип. 120. С. 116-126. 